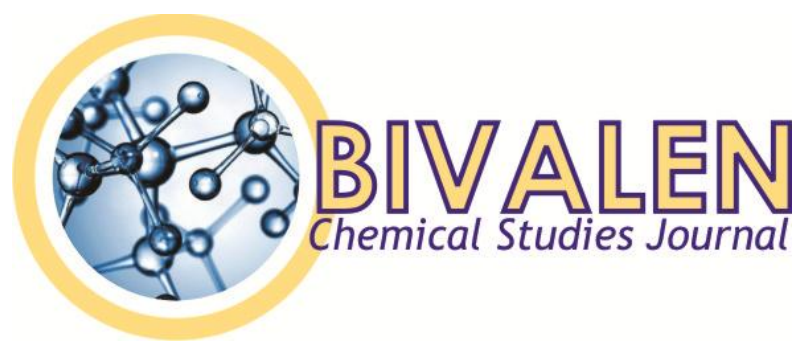

\title{
PENGARUH PENGGUNAAN MODEL PEMBELAJARAN MAKE A MATCH DALAM MODEL PEMBELAJARAN TEAM GAMES TOURNAMENT TERHADAP HASIL BELAJAR SISWA SMA PADA POKOK BAHASAN TATA NAMA SENYAWA
}

\section{THE EFECT OF MAKE A MATCH LEARNING MODEL IN TEAM GAMES TOURNAMENT LEARNING MODEL ON SENIOR HIGH SCHOL STUDENT'S LEARNING OUTCOMES OF COMPOUND'S NOMENCLATURE}

\author{
Djainur Aryati*1, Usman ${ }^{2}$, Abdul Majid ${ }^{2}$ \\ ${ }^{\text {I}}$ Program Studi Sarjana Pendidikan Kimia, Fakultas Keguruan dan Ilmu Pendidikan, Universitas Mulawarman, \\ Samarinda Kalimantan Timur, Indonesia \\ ${ }^{2}$ Program Studi Pascasarjana Pendidikan Kimia, Fakultas Keguruan dan Ilmu Pendidikan, Universitas \\ Mulawarman, Samarinda Kalimantan Timur, Indonesia \\ *Corresponding Author: djainuraryati1995@gmail.com (+6285252122657)
}

\begin{abstract}
ABSTRAK
Penelitian ini bertujuan untuk mengetahui pengaruh penggunaan model pembelajaran make a match dalam model pembelajaran team games tournament (TGT) terhadap hasil belajar siswa SMA pada pokok bahasan tata nama senyawa. Jenis penelitian ini tergolong quasi experiment. Penelitian ini dilaksanakan di SMA Negeri 5 Samarinda, Kalimantan Timur, Indonesia. Subjek peneliti adalah siswa kelas X IPA 1 (kelas eksperimen, 32 siswa) dan kelas X IPA (kelas $^{2}$ kontrol, 31 siswa) yang dipilih menggunakan teknik purposive sampling. Model pembelajaran yang digunakan untuk kelas eksperimen adalah model pembelajaran make a match dalam model pembelajaran TGT dan model pembelajaran yang digunakan untuk kelas kontrol adalah model pembelajaran TGT. Ada tiga data yang digunakan dalam penelitian ini yaitu (1) data dokumentasi berupa nilai hasil belajar siswa pada pokok bahasan sebelumnya, (2) nilai tes kemampuan kognitif siswa yang diperoleh dari $25 \%$ nilai post-test pertemuan pertama, $25 \%$ nilai post-test pertemuan kedua dan $50 \%$ nilai ulangan harian, dan (3) data aktivitas siswa yang diperoleh melalui observasi. Hasil penelitian menunjukkan bahwa terdapat pengaruh penggunaan model pembelajaran make a match dalam model pembelajaran TGT terhadap hasil belajar siswa SMA pada pokok bahasan tata nama senyawa.
\end{abstract}

Kata Kunci : hasil belajar, tata nama senyawa, make a match, TGT

\section{ABSTRACT}

This study aimed to determine the effect of implementation of make a match learning model in team games tournament (TGT) learning model on senior high school students's learning utcome of compound nomenclature. This research was classified as quasi experiment. This research was conducted at SMA N 5 Samarinda, Kalimantan Timur, Indonesia. Subject of research was students tenth grade of natural science 1 (experimental group, 32 students) and students tenth grade of natural science 2 (control group, 31 students) which was selected using purposive sampling technique. The learning model implemented in the experimental group was make a match learning model in TGT learning model and the learning model implemented in control group was the TGT learning model. There were three data used in this research i.e. (1) documentation data which were students learning outcome before experiment, (2) students's cognitive ability test that obtained from $25 \%$ of $1^{\text {st }}$ post test score, $25 \%$ of $2^{\text {nd }}$ post test score and $50 \%$ chapter examination score, and (3) student activity data that obtained by observation. Result of this research showed that the implementation of make a match learning model in TGT learning model effect the senior high school student's learning outcome of compound nomenclature.

Keywords : learning outcomes, compound's nomenclature, make a match, TGT 


\section{PENDAHULUAN}

Model pembelajaran yang banyak digunakan dalam kimia adalah model pembelajaran TGT. Model pembelajaran TGT adalah salah satu model pembelajaran yang menempatkan siswa dalam kelompok-kelompok yang memiliki kemampuan, jenis kelamin dan suku kata yang berbeda. Pada model ini siswa memainkan permainan dengan anggota-anggota tim lain untuk memperoleh tambahan poin untuk skor tim mereka. Penggunaan model pembelajaran TGT dapat digunakan untuk meningkatkan hasil belajar dan presentase ketuntasan siswa dari 59\% menjadi $84 \%$ (Yanti, 2014). Penerapan model pembelajaran TGT menuntut keaktifan peserta didik sehingga pembelajran tidak terpusat pada guru. Dalam model pembelajaran TGT terdapat 5 sintak pembelajaran yaitu penyajian kelas, pembagian kelompok, game tournament, evaluasi dan penghargaan kelompok (Slavin, 2009).

Model pembelajaran lain yang dapat digunakan dalam pembelajaran kimia adalah model pembelajaran make a match. Model pembelajaran ini merupakan salah satu alternatif yang dapat diterapkan untuk meningkatkan aktivitas siswa di dalam kelas. Melalui model ini siswa berperan aktif dengan mencari pasangan kartu jawaban dari kartu soal yang diberikan guru. Presentase ketuntasan siswa dapat ditingkankan dari $79 \%$ menjadi $91 \%$ dengan penerapan model pembelajaran make a match (Gita,2014).

Kedua model pembelajran yang disebutkan diatas merupakan model pembelajaran yang melibatkan permainan. Permainan yang ada di dalam model pembelajaran make a match dapat dilaksanakan dalam games tournament yang ada dalam model pembelajaran TGT. Penerapan permainan mencari pasangan kartu jawaban dari kartu soal yang diberikan guru dalam model pembelajaran make a match sangat cocok diterapkan dalam pembelajaran materi tata nama senyawa. Presentase ketuntasan belajar siswa meningkat dari $36,18 \%$ menjadi $82,97 \%$ dengan penerapan kolaborasi model pembelajaran make a match dan TGT pada materi tata nama senyawa (Dino, 2014).

Berdasarkan uraian di atas, penelitian ini dilaksanakan untuk mengetahui pengaruh penerapan mode pembelajaran make a match dalam model pembelajaran TGT pada pokok bahasan tata nama senyawa.

\section{METODE PENELITIAN}

Penelitian ini dilakukan di SMAN 5 Samarinda Kalimantan Timur, Indonesia pada tahun ajaran 2016/2017. Jenis penelitian ini terglong dalam quasi experimental design dengan menggunakan model nonequivalent control group design. Pemilihan subjek penelitian dilakukan dengan teknik purposive sampling. Subjek penelitian adalah siswa kelas $\mathrm{X}$ $\mathrm{IPA}_{1}$ yang merupakan kelas eksperimen dan kelas $\mathrm{X}$ $\mathrm{IPA}_{2}$ yang merupakan kelas kontrol. Kelas eksperimen diajar dengan menggunakan model pembelajaran make a match dalam model pembelajaran TGT, dan kelas kontrol diajar dengan menggunakan model pembelajaran TGT (tanpa model pembelajaran make a match). Pokok bahasan yang diajarkan dalam penelitian ini adalah materi tata nama senyawa.

Teknik pengumpulan data dalam penelitian ini adalah menggunakan teknik dokumentasi, tes dan observasi. Data dokumentasi berupa nilai hasil belajar siswa kelas eksperimen dan kelas kontrol pada pokok bahasan sebelumnya yang digunakan untuk uji homogenitas subjek penelitian (lihat Tabel 1). Data tes hasil belajar siswa diperoleh dari $25 \%$ nilai post-test pertemuan pertama, $25 \%$ nilai posttest pertemuan kedua dan $50 \%$ nilai ulangan harian. Soal post-test terdiri atas 6 buah soal essay dan ulangan harian terdiri atas 20 buah soal pilihan ganda. Data observasi digunakan untuk mengetahui aktivitas guru dan siswa selama pembelajaran. Validasi instrument (soal post-test, soal ulangan harian dan lembar observasi) penelitian dengan menggunakan pengujian construct validity yaitu validitas menggunakan pendapat ahli (Sugiono, 2016). Validator instrumen dalam penelitian ini adalah 4 dosen di Program Studi Sarjana Pendidikan Kimia, FKIP, Universitas Mulawarman. Ada tidaknya pengaruh penerapan model pembelajaran make a match dalam model pembelajaran TGT dianalisis menggunakan uji $\mathrm{t}$ dengan $\alpha=5 \%$ (Pramudjono,2011).

\section{HASIL DAN PEMBAHASAN}

Penerapan model pembelajaran make a match dalam model pembelajran TGT memiliki tahapan yang sama dengan model pembelajaran TGT, akan tetapi di dalam tahap game tournaments, jenis permainan yang digunakan adalah permainan yang ada dalam make a match. Pertama-tama siswa diberikan penjelasan tentang materi tata nama senyawa oleh guru, kemudian siswa belajar kelompok sesuai kelompok dengan kelompok 
masing-masing untuk mendalami materi yang telah sampaikan oleh guru. Pada tahap belajar kelompok, siswa yang memiliki kemampuan akademik yang lebih memberikan penjelasan ulang dan meyakinkan setiap anggota kelompok memahami materi yang telah disampaikan oleh guru. Pada tahap game tournaments masing-masing siswa yang memiliki kemampuan yang sama dari setiap kelompok ditempat kan dalam satu meja tournament yang sama untuk melakukan permainan. Pada kelas eksperimen, permainan yang diberikan adalah permainan dalam model pembelajaran make a match. Setiap siswa dimasing-masing meja tournament diberi kartu soal dan mencari pasangan kartu jawaban yang cocok. Pada kelas kontrol, permainan yang diberikan adalah permainan dalam model pembelajaran TGT, dimana setiap perwakilan kelompok dengan kemampuan yang sama diminta untuk menuliskan jawaban soal dari kartu soal yang dibacakan. Pada tahap akhir, masing-masing kelompok diberikan skor dan penghargaan sesuai dengan keberhasilan jawaban dan aturan permainan.

Hasil belajar siswa kelas eksperimen yaitu siswa yang diajar dengan menggunakan model pembelajaran make a match dalam model pembelajaran TGT dan hasil belajar siswa kelas kontrol yaitu siswa yang diajar menggunakan model pembelajaran TGT (tanpa model pembelajaran make a match) disajikan dalam Tabel 1.

Tabel 1

Data rata-rata hasil belajar Nilai Hasil Belajar Siswa

\begin{tabular}{lcc}
\multicolumn{1}{c}{ Kelas } & $\begin{array}{c}\text { Sebelum } \\
\text { Perlakuan }\end{array}$ & $\begin{array}{c}\text { Setelah } \\
\text { Perlakuan }\end{array}$ \\
\hline Eksperimen & 68,5 & $80,2^{*}$ \\
Kontrol & 65,2 & 72,6 \\
\hline
\end{tabular}

*Berbeda dengan kelas kontrol pada kolom yang sama $(\alpha=5 \%)$

Dari Tabel 1 tampak bahwa rata-rata hasil belajar siswa kelas eksperimen lebih tinggi dari hasil belajar siswa kelas kontrol dan kedua rata-rata hasil belajar ini berbeda secara signifikan ( $\alpha=5 \%)$. Perbedaan signifikan ini menunjukkan bahwa penerapan model pembelajaran make a match dalam model pembelajaran TGT berpengaruh terhadap dan dapat meningkatkan hasil belajar siswa pada pokok bahasan tata nama senyawa. Hal ini terjadi karena penerapan model pembelajaran make a match di dalam tahapan game tournament model pembelajran TGT, menuntut siswa berlomba menemukan jawaban yang telah disediakan, sehingga semangat siswa untuk menemukan jawaban lebih tinggi. Adanya pilihan-pilihan jawaban, meskipun terdapat pilihan jawaban lain sebagai pengecoh, dapat membantu siswa untuk mengingat dan menemukan jawaban yang tepat, akibatnya siswa lebih tertantang dan semangat untuk menemukan jawaban dan menjadi pemenang. Kondisi ini dapat meningkatkan motivasi dan semangat yang lebih tinggi di dalam diri siswa, khususnya siswa dengan kemampuan akademik menengah kebawah. Pada model pembelajaran TGT, siswa dituntut untuk mengingat dan menjawab dengan benar. Pada keadaan ini siswa tidak memiliki bantuan atau clue untuk menjawab dengan tepat. Kondisi seperti ini akan menyulitkan bagi siswa untuk dapat menjawab dengan tepat, khususnya siswa dengan kemampuan daya ingat yang rendah dan berakibat pada menurunnya minat dan motivasinya. Menurut Herminanto Sofyan dan Hamzah Uni dalam Artawa (2013), proses permainan merupakan proses yang menarik bagi siswa. Suasana yang menarik menyebabkan kegiatan belajar mengajar bermakna secara efektif atau emosional bagi peserta didik. Sesuatu yang bermakna akan lebih lama diingat dan dipahami. Jadi pembelajaran yang lebih menarik akan menjadikan siswa lebih lama dalam menyimpan apa yang pernah dipelajarinya.

\section{SIMPULAN}

Berdasarkan hasil penelitian dan analisis data yang telah dilakukan dapat disimpulkan bahwa terdapat pengaruh model pembelajaran make a match dalam model pembelajaran TGT terhadap hasil belajar siswa di SMA Negeri 5 Samarinda tahun ajaran 2016/2017 pada materi tata nama senyawa.

\section{UCAPAN TERIMAKASIH}

Ucapan terima kasih dan penghargaan yang setinggi-tingginya atas kerja samanya kepada SMA Negeri 5 Samarinda yang telah mengijinkan penulis melakukan penelitian.

\section{DAFTAR PUSTAKA}

Artawa, I.G.R., \& Suwarta, I.I.W. (2013). Pengaruh model pembelajaran kooperatif tipe make a match terhadap prestasi belajar matematika siswa kelas V SD di Gugud 1 Kecamatan Selat. Mimbar PGSD Undiksha, 1(1).

Dino. (2014). Pembelajaran make a match dan teams games tournament (TGT). Jurnal Pendidikan Kimia, 3(3), 31-39. 
Gita. (2014). Model Pembelajaran kooperatif tipe make a match. J. Kaunia, 10(20), 128-140.

Pramudjono. (2011). Statistika dasar aplikasi untuk penelirian, Samarinda: Purry Kencana Mandiri.

Slavin. (2009). Cooperative learning: teori, riset dan praktik. Bandung: Nusa Media.

Sugiono. (2016). Metode penelitian pendidikan. Bandung:Alfabeta.

Yanti. (2014). Model pembelajaran kooperatif tipe teams games tournament (TGT). Jurnal Pendidikan dan Keguruan, 1(1), 20-32. 